\title{
Hubungan Pengetahuan Ibu Nifas Dengan Upaya Pencegahan Infeksi Nifas Di Desa Tanjung Siambang Kota Tanjung Pinang Tahun2019
}

\author{
Sumiyati \\ Program Studi Ilmu Keperawatan, STIKes Awal Bros Batam \\ Email : $\underline{\text { Sumiyati170879@gmail.com }}$
}

\begin{abstract}
ABSTRAK
Angka kematian ibu di Indonesia dalam Survey Demografi dan Kesehatan Indonesia (SDKI) menunjukkan bahwa Angka Kematian Ibu (AKI) di Indonesia sebesar 307/100.000 kelahiran hidup. AKI di Indonesia masih relatif tinggi jika dibandingkan negara-negara ASEAN, infeksi nifas merupakan penyebab kematian terbanyak nomor dua setelah perdarahan selama masa nifas, sehingga diperlukan adanya pemantauan selama masa nifas. Adapun tujuan penelitian ini untuk mengetahui hubungan pengetahuan ibu nifas dengan upaya pencegahan infeksi nifas di desa tanjung siambang kota tanjung pinang. Jenis penelitian ini deskriptif kuantitatif dengan pendekatan cross sectional. Metode pengambilan sampel dalam penelitian ini secara total sampling atau sampling jenuh. Sampel dalam penelitian ini terdiri dari 36 orang ibu nifas. Metode dan alat pengumpulan data menggunakan kuesioner. Analisa data dilakukan dengan uji Chi Square dengan taraf kepercayaan $95 \%$. Hasil penelitian menunjukkan sebagian besar ibu memiliki pengetahuan pada kategori cukup yaitu sebesar 16 orang $(44,4 \%)$, dan diketahui sebagian besar ibu nifas memiliki upaya pencegahan infeksi nifas pada kategori kurang yaitu sebesar 22 orang $(61,1 \% \%)$. Kesimpulan dari analisa data diketahui ada hubungan antara pengetahuan ibu nifas dengan upaya pencegahan infeksi nifas di Desa Tanjung Siambang kota Tanjungpinang dengan nilai signifikan $\mathrm{p}$ value $=0,000<0,05$. Saran bagi petugas kesehatan agar lebih sering memberikan penyuluhan kepada ibu nifas tentang tanda bahaya infeksi nifas dan pencegahannya, agar cakupan kejadian infeksi nifas menurun.
\end{abstract}

Kata Kunci: Pengetahuan, Masa Nifas, Infeksi Nifas

Daftar Pustaka: 24 (2011-2019) 


\title{
The Relationship between Postpartum Mother Knowledge and Prevention of Childbirth Infection in Tanjung Siambang Village, Tanjung Pinang City, 2019
}

\begin{abstract}
The maternal mortality rate in Indonesia in the Indonesian Demographic and Health Survey (SDKI) shows that the Maternal Mortality Rate (MMR) in Indonesia is 307 / 100,000 live births. AKI in Indonesia is still relatively high compared to ASEAN countries, puerperal infection is the second most leading cause of death after bleeding during the puerperium, so monitoring is needed during the puerperium. The purpose of this study was to determine the relationship of postpartum maternal knowledge with prevention of puerperal infection in the village of Tanjung Siambang, Tanjung Pinang. This type of research is quantitative descriptive with cross sectional approach. The sampling method in this study was total sampling or saturated sampling. The sample in this study consisted of 36 postpartum mothers. Data collection methods and tools use a questionnaire. Data analysis was performed using the Chi Square test with a 95\% confidence level. The results showed that most mothers had sufficient knowledge in the category of 16 people $(44.4 \%)$, and it was known that most of the postpartum mothers had an effort to prevent postpartum infection in the less category of 22 people $(61.1 \% \%)$. The conclusion from the analysis of the data is known that there is a relationship between the knowledge of puerperal mothers and prevention of puerperal infection in Tanjung Siambang Village, Tanjungpinang City with a significant value of $\mathrm{p}$ value $=0,000<0.05$. Suggestions for health workers to more often provide counseling to postpartum mothers about the danger signs of puerperal infection and its prevention, so that the scope of the incidence of puerperal infection decreases.
\end{abstract}

Keywords: Knowledge, Postpartum Period, Postpartum Infection

Bibliography: 24 (2011-2019)

\section{PENDAHULUAN}

Infeksi nifas merupakan penyebab kematian terbanyak nomor dua setelah perdarahan selama masa nifas, sehingga diperlukan adanya pemantauan selama masa nifas. Adanya permasalahan pada masa nifas akan berimbas pada kesejahteraan bayi yang dilahirkannya, karena bayi tidak akan mendapatkan perawatan maksimal dari ibunya. Akibatnya, angka kesakitan dan kematian bayi pun akan meningkat
(Saleha, 2014).

Banyak ibu nifas yang mengalami masalah bahaya masa nifas, yang tidak di ketahui atau terdeteksi oleh tenaga kesehatan. Penyebab tidak di ketahuinya masalah bahaya masa nifas yaitu kurangnya pengetahuan ibu nifas. Dimana yang mempengaruhi pengetahuan dari ibu nifas yaitu faktor (pendidikan, usia, pekerjaan, informasi, pengalaman, lingkungan, sosial ekonomi, sosial 
budaya) dan juga konseling dari tenaga kesehatan selama kehamilan dan setelah persalinan (Notoadmodjo, 2005).

Menurut penelitian Meni Fuzi Astuti Tanjung (2017) dengan judul "Tingkat Pengetahuan Ibu Nifas Tentang Komplikasi Masa Nifas di Puskesmas Pulau Bandring " pengetahuan ibu nifas tentang komplikasi masa nifas mayoritas berpengetahuan kurang sebanyak 20 orang $(47,62 \%)$ dan minoritas berpengetahuan baik sebanyak 9 orang (21,43\%). Hal ini menyebabkan masih tinggi angka kejadian infeksi pada ibu nifas di Pulau Badring yang disebabkan kurangnya pengetahuan ibu tentang tanda bahaya pada masa nifas.

Berdasarkan data dari Puskesmas pembantu Desa Tanjung Siambang yaitu salah satu wilayah kerja Puskesmas Sei.Jang, terdapat 325 ibu yang pernah melahirkan tahun 2019, dari jumlah tersebut terdapat 6 kasus komplikasi obstetri, yaitu 4 kasus perdarahan setelah persalinan dan 2 kasus infeksi pasca persalinan di Desa Tanjung Siambang, dimana kasus kematian akibat persalinan dan infeksi pasca persalinan paling tinggi dari seluruh desa diwilayah kerja puskesmas Sei.Jang, hal ini disebabkan rendahnya pengetahuan masyarakat dan masih kuatnya menganut budaya setempat, rendahnya pengetahuan masyarakat di Desa Tanjung Siambang diketahui dari tingkat pendidikan masyarakat yang dominan hanya tamatan SMP.
Pendidikan tertinggi masyarakat Desa Dompak Seberang yang paling banyak adalah SMA, hal ini disebabkan karena tingkat ekonomi masyarakat yang masih rendah, sebagian besar masyarakat bekerja sebagai nelayan.

Berdasarkan studi pendahuluan yang dilakukan di Pustu Desa Tanjung Siambang dengan menggunakan 5 pertanyaan diperoleh data yaitu dari $10 \mathrm{ibu}$ nifas, 3 ibu nifas mengetahui tentang infeksi masa nifas dan 7 ibu nifas kurang mengetahui tentang infeksi masa nifas. Dari 10 ibu nifas tersebut hanya $2 \mathrm{ibu}$ nifas yang tahu cara pencegahan agar tidak terjadinya infeksi nifas.

Berdasarkan uraian diatas, peneliti tertarik untuk melakukan penelitian hubungan pengetahuan ibu nifas dengan upaya pencegahan infeksi nifas di desa Tanjung Siambang Kota Tanjung Pinang.

\section{METODELOGI PENELITIAN}

Jenis penelitian yang digunakan pada penelitian ini adalah deskriptif kuantitatif dengan pendekatan cross sectional. Penelitian ini bertujuan untuk menganalisa hubungan pengetahuan ibu dengan upaya pencegahan infeksi nifas di Desa Tanjung Siambang Kota Tanjungpinang. Pada penelitian ini sebagai populasinya adalah seluruh ibu nifas di Desa Tanjung Siambang yaitu berjumlah 36 orang. Pada penelitian ini, peneliti menggunakan teknik sampel jenuh atau total sampling yaitu teknik penentuan sampel dengan cara 
mengambil seluruh anggota populasi sebagai responden atau sampel yaitu 36 orang.

\section{HASIL PENELITIAN \\ Karakteristik Responden}

Tabel 4.1 Karakteristik Responden di Desa Tanjung Siambang

\begin{tabular}{l|c|c}
\hline Karakteristik & F & \% \\
\hline Usia & & \\
< 20 tahun & 13 & 36,1 \\
$\mathbf{2 0 - 3 5}$ tahun & 18 & 50 \\
$>\mathbf{3 5}$ tahun & 5 & 13,9 \\
Jumlah & $\mathbf{3 6}$ & $\mathbf{1 0 0}$ \\
\hline Pendidikan & & \\
Terakhir & 3 & 8,3 \\
Tidak tamat SD & 7 & 19,4 \\
SD & 13 & 36,1 \\
SMP & 9 & 25 \\
SMA & 4 & 11,1 \\
Diploma/sarjana & $\mathbf{3 6}$ & $\mathbf{1 0 0}$ \\
Jumlah & & \\
\hline Pekerjaan & & \\
IRT & 16 & 44,4 \\
Buruh & 8 & 22,2 \\
Petani & 3 & 8,3 \\
Swasta/wiraswasta & 6 & 16,7 \\
PNS & 3 & 8,3 \\
Jumlah & $\mathbf{3 6}$ & $\mathbf{1 0 0}$ \\
\hline
\end{tabular}

Berdasarkan tabel 4.1 diketahui bahwa umur responden penelitian di Desa Tanjung Siambang sebagian besar berada

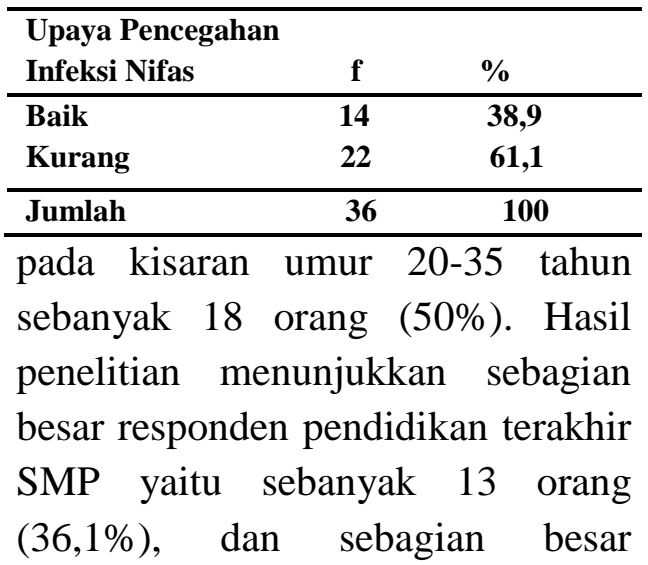

Berdasarkan hasil penelitian, diperoleh karakteristik responden yang meliputi umur, pendidikan terakhir, dan pekerjaan dapat dilihat pada tabel dibawah ini:

responden sebanyak 16 orang $(44,4 \%)$ adalah ibu rumah tangga.

\section{Analisa Univariat}

a. Pengetahuan

Berdasarkan hasil penelitian, persentase pengetahuan ibu dapat dilihat pada tabel berikut:

Tabel 4.2 Distribusi Frekuensi pengetahuan Ibu di Desa Tanjung Siambang kota Tanjungpinang Tahun 2019

\begin{tabular}{lcc}
\hline Pengetahuan & f & $\%$ \\
\hline Kurang & 11 & 30,6 \\
Cukup & 16 & 44,4 \\
Baik & 9 & 25 \\
\hline Jumlah & 36 & 100 \\
\hline
\end{tabular}

Berdasarkan tabel 4.2 diketahui sebagian besar responden memiliki pengetahuan pada kategori cukup yaitu sebesar 16 orang $(44,4 \%)$.

b. Upaya Pencegahan Infeksi Nifas

Dari hasil penelitian yang dilakukan, distribusi frekuensi upaya pencegahan infeksi nifas dapat dilihat pada tabel dibawah ini:

Tabel 4.3 Distribusi Frekuensi Upaya Pencegahan Infeksi Nifas di Desa Tanjung Siambang Kota Tanjungpinang Tahun 2019

Berdasarkan tabel 4.3 diketahui sebagian besar responden memiliki upaya pencegahan infeksi nifas pada kategori kurang yaitu sebesar 22 orang $(61,1 \%)$.

\section{Analisis Bivariat}


Hubungan Pengetahuan Ibu nifas dengan Upaya Pencegahan Infeksi Nifas di Desa Tanjung Siambang Kota Tanjungpinang tahun2019.

Hubungan pengetahuan Ibu dengan upaya pencegahan infeksi nifas dapat dilihat pada tabel dibawah ini:

\section{Tabel 4.4}

Hubungan Pengetahuan Ibu dengan Upaya Pencegahan Infeksi Nifas di Desa Tanjung Siambang Kota Tanjungpinang tahun 2019

Berdasarkan tabel 4.4 diatas, hasil uji statistik dengan uji chi square menunjukkan hasil nilai signifikan atau Sig. (2-tailed) pada variabel pengetahuan ibu dengan upaya pencegahan infeksi nifas yaitu sebesar $0,000<0,05$, maka dapat disimpulkan ada hubungan antara pengetahuan ibu dengan upaya pencegahan infeksi nifas di Desa Tanjung Siambang Kota Tanjungpinang Tahun 2019.

Hasil tabulasi silang diketahui bahwa dari 11 resonden dengan pengetahuan kurang, 9 (38,9\%) responden memiliki upaya pencegahan infeksi nifas yang kurang, dan $2(5,6 \%)$ responden memiliki upaya pencegahan infeksi nifas yang baik, sedangkan dari 16 $(44,4 \%)$ responden dengan

\begin{tabular}{|c|c|c|c|c|c|c|c|}
\hline \multirow{2}{*}{$\begin{array}{c}\text { Pengetah } \\
\text { uan }\end{array}$} & \multicolumn{4}{|c|}{ Upaya pencegahan infeksi nifas } & \multirow[b]{2}{*}{$\begin{array}{c}\text { Tota } \\
1\end{array}$} & & \multirow{2}{*}{$\begin{array}{c}\text { Sig. } \\
(2- \\
\text { tailed)/ } \\
\text { p value }\end{array}$} \\
\hline & Kurang & $\%$ & Baik & $\%$ & & & \\
\hline Kurang & 9 & 25 & 2 & 5,6 & 11 & 30,6 & 0,000 \\
\hline Cukup & 13 & 36,1 & 3 & 8,3 & 16 & 44,4 & \\
\hline Baik & 0 & 0,0 & 9 & 25 & 9 & 25 & \\
\hline Total & 22 & 61,1 & 14 & 38,9 & 36 & 100 & \\
\hline
\end{tabular}

$(36,1 \%)$ responden memiliki upaya pencegahan infeksi nifas yang kurang, $3(8,3 \%)$ responden yang memiliki upaya pencegahan infeksi nifas yang baik. Kemudian dari 9 (25\%) responden dengan pengetahuan baik memiliki upaya pencegahan baik yaitu sebesar 9 (25\%) responden, dan responden yang memiliki pengetahuan baik tidak ada satupun yang memiliki upaya pencegahan infeksi nifas yang kurang.

\section{PEMBAHASAN}

Hubungan Pengetahuan Ibu dengan upaya Pencegahan Infeksi Nifas di Desa Tanjung Siambang kota Tanjungpinang T.A 2019.

Berdasarkan hasil penelitian dengan uji chi square menunjukkan hasil nilai signifikan atau Sig. (2-tailed) pada variabel pengetahuan ibu dengan upaya pencegahan infeksi nifas yaitu sebesar $0,000<0,05$, maka dapat disimpulkan ada hubungan antara pengetahuan ibu dengan upaya pencegahan infeksi nifas di Desa Tanjung Siambang Kota Tanjungpinang Tahun 2019. Hasil tabulasi silang diketahui bahwa dari 11 resonden dengan pengetahuan kurang, 9 (38,9\%) responden memiliki upaya pencegahan infeksi nifas yang kurang, dan $2(5,6 \%)$ responden memiliki upaya pencegahan infeksi nifas yang baik, sedangkandari $16 \quad(44,4 \%)$ responden dengan pengetahuan yang cukup, 13 (36,1\%). Hal ini membuktikan bahwa pengetahuan 
ibu dapat berdampak pada upaya pencegahan infeksi nifas. Semakin tinggi tingkat pengetahuan ibu maka akan semakin baik upaya pencegahan infeksi nifas.

Apabila melihat adanya hubungan antara pengetahuan ibu dengan upaya pencegahan infeksi nifas di Desa Tanjung Siambang kota Tanjungpinang, maka dapat disimpulkan bahwa semakin baik pengetahuan ibu maka semakin baik pula untuk melakukan pencegahan infeksi nifas. Sebaliknya rendahnya pengetahuan ibu maka akan tidak baik juga untuk melakukan pencegahan terjadinya infeksi nifas. Pengetahuan ibu sebagai landasan untuk melakukan perawatan nifas yang lebih baik sesuai dengan ilmu kesehatan sehingga upaya pencegahan terjadinya infeksi nifas dapat dilakukan dengan baik. Pengetahuan didapat dari tingkat pendidikan seseorang, semakin tinggi tingkat pendidikan maka semakin tinggi juga pengetahuan. Dan semakin tinggi pengetahuan seseorang maka akan semakin baik perilaku kesehatannya.

Peningkatan pengetahuan dapat diperoleh dari berbagai sumber informasi salah satunya dengan pendidikan kesehatan, dimana pendidikan kesehatan dapat diperoleh dari petugas kesehatan, dalam hal ini peran bidan dalam memberikan pengetahuan tentang perawatan nifas dan bagaimana cara pencegahan agar tidak terjadi infeksi pada masa nifas. Pengetahuan sangat perlu untuk meningkatkan kesehatan masyarakat.

Hal ini sejalan dengan teori Notoatmojo (dalam Nursalam 2016), pengetahuan merupakan hasil dari tahu, dan ini terjadi setelah orang melakukan penginderaan terhadap suatu objek tertentu. Menurut Syafrudin (dalam Nursalam, 2016), pengetahuan yang setengahsetengah justru lebih berbahaya dari pada tidak tahu sama sekali. Pembentukan pengetahuan sendiri dipengaruhi oleh faktor internal yaitu cara individu dalam menanggapi pengetahuan tersebut dan eksternal yang merupakan stimulus untuk mengubah pengetahuan tersebut menjadi lebih baik.

Sesuai dengan hasil penelitian bahwa faktor internal disini adalah tingkat pendidikan responden sebagian besar adalah SMP, artinya tingkat pendidikannya masih kategori cukup, kemudian umur yang diketahui sebagian besar responden berumur 20-35 tahun yang artinya umur yang dianggap sudah matang dalam memperoleh pengetahuan. Faktor eksternal yang mempengaruhi pengetahuan responden dalam penelitian ini adalah pekerjaan, diketahui sebagian besar responden bekerja sebagai ibu rumah tangga. Lingkungan pekerjaan dapat menjadikan seseorang dalam 
memperoleh pengalaman dan pengetahuan baik secara langsung maupun tidak langsung (Nursalam, 2016).

Dari hasil wawancara yang dilakukan dengan beberapa responden yang menjadi informan menyatakan bahwa adanya pantangan-pantangan dalam masa nifas seperti makanan/minuman yang dikonsumsi setelah melahirkan adalah minuman rempah-rempah, tidak boleh minum air dingin atau air putih yang tidak hangat. Makan harus kering, seperti ikan bakar dengan nasi putih hangat, tidak boleh mengkonsumsi buah-buahan yang banyak mengandung air. Pantang makanan tertentu seperti daging, ikan dan telur dipercaya dapat menyebabkan bengkak dan gatalgatal serta memperlambat penyembuhan luka persalinan. Hal ini sangat bertentangan dengan anjuran medis, dimana ibu-ibu dalam masa nifas harus tercukupi nutrisi untuk proses penyembuhan, kekurangan asupan gizi dapat menyebabkan berpotensi terjadinya anemia dalam masa nifas dan akhirnya dapat terjadi perdarahan dan infeksi pada masa nifas. Disamping itu nutrisi penting dalam pembentukan ASI yang merupakan makanan utama bagi anak.

Selama masa nifas (40 hari), ibu tidak boleh melakukan aktivitas didalam rumah maupun diluar rumah, ibu dianjurkan istirahat dan tidur setengah duduk.
Menurut responden, istirahat ini bertujuan untuk mempercepat penyembuhan luka setelah persalinan. Tindakan tersebut sangat bertentangan dengan prinsip ambulasi, dimana setelah 6 jam persalinan ibu boleh berjalan atau melakukan aktivitas sesuai dengan kemampuannya. Hal ini bertujuan untuk mempercepat proses involusio dan mempercepat pengeluaran lochea atau sisa-sisa darah dari jalan lahir yang dapat merupakan media perkembangan mikroorganisme yang dapat menyebabkan infeksi pada masa nifas.

Hal ini sejalan dengan penelitian yang dilakuka oleh Lidya (2019) diketahui 6 (60.0\%) responden mempunyai pencegahan komplikasi nifas negative, sebagian besar memiliki pengetahuan rendah sebanyak 6 responden $(60.0 \%)$,

Penelitian ini juga sejalan dengan penelitian florentina Prisna (2017) bahwa terdapat hubungan yang bermakna secara statistik antara pengetahuan ibu tentang tanda bahaya infeksi nifas dengan kejadian infeksi nifas dengan nilai korelasi sebesar 0,552 dengan significansi $0,001 \quad(<0,05)$.

Menurut asumsi peneliti pelaksanakan pencegahan infeksi nifas tidak berjalan dengan maksimal dimana terdapat beberapa responden yang tidak tahu bagaimana cara melakukan pencegahan infeksi nifas. Pencegahan infeksi nifas tidak 
hanya dilakukan dengan berkunjungan ke Puskesmas atau Kunjungan rumah oleh petugas kesehatan saja tetapi ibu nifas juga harus melakukan semua anjuran yang diberikan oleh petugas kesehatan agar terhindar dari infeksi nifas. Upaya-upaya yang dapat dilakukan untuk meningkatkan pencegahan infeksi nifas yaitu dengan cara memberikan ibu konseling setiap ibu nifas melakukan kunjungan nifas dan mengingatkan ibu kembali atau menjelaskan cara melakukan pencegahan infeksi nifas yang dapat dilakukan dengan kunjungan rumah.

\section{KESIMPULAN DAN SARAN KESIMPULAN}

1. Hasil penelitian gambaran pengetahuan ibu, menunjukkan bahwa sebagian besar responden memiliki pengetahuan pada kategori cukup sebanyak 16 orang $(44,4 \%)$

2. Hasil penelitian gambaran upaya pencegahan infeksi nifas, menunjukkan bahwa sebagian besar responden memiliki pengetahuan pada kategori kurang sebanyak 22 orang $(61,1 \%)$

3. Berdasarkan hasil penelitian dengan menggunakan hasil uji statistik dengan uji chi square menunjukkan hasil nilai signifikan atau Sig. (2-tailed) pada variabel pengetahuan ibu dengan upaya pencegahan infeksi nifas yaitu sebesar $0,000<0,05$, maka dapat disimpulkan ada hubungan antara pengetahuan ibu dengan upaya pencegahan infeksi nifas di Desa Tanjung Siambang Kota Tanjungpinang Tahun 2019.

\section{SARAN}

1. Bagi petugas kesehatan

Petugas kesehatan agar lebih sering memberikan penyuluhan kepada ibu nifas tentang tanda bahaya infeksi nifas dan pencegahannya, agar cakupan kejadian infeksi nifas menurun.

2. Bagi Masyarakat/Responden Untuk lebih meningkatkan pengetahuan tentang tanda bahaya infeksi nifas dan bagaimana cara pencegahan infeksi nifas, dan lebih baik lagi dapat memberikan pengetahuan tentang tanda bahaya infeksi nifas kepada orang lain.

3. Bagi Peneliti Selanjutnya Penelitian ini hendaknya dilakukan lagi pada masa yang akan datang untuk mengetahui perkembangan yang telah terjadi dengan mengacu pada hasil penelitian ini

\section{DAFTAR PUSTAKA}

Achyar, K., \& Rofiqoh, I. (2016). Pengaruh Kunjungan Nifas Terhadap Komplikasi Masa Nifas di Wilayah Puskesmas Sokaraja 1 Kabupaten Banyumas. MEDISAINS: Jurnal Ilmiah Ilmu-Ilmu Kesehata.

Amini, A., Pamungkas, C. E., \& Harahap, A. P. H. P. (2018). USIA IBU DAN PARITAS 
Ananto Wibrata Jurusan

Keperawatan, D., Kesehatan

Kemenkes Surabaya Nursalam

Fakultas Keperawatan, P.,

Airlangga Siti Nurkholifah

Jurusan Keperawatan, U., \&

Kesehatan Kemenkes Surabaya,

P. (2017). MODEL HUMAN

INTERACTION DAN

HEALTH PROMOTION

SEBAGAI UPAYA

PENINGKATAN KINERJA

PERAWAT DI PONDOK

KESEHATAN DESA

(PONKESDES) JAWA TIMUR.

GLOBAL HEALTH SCIENCE.

Arikunto. (2019). Metodelogi

Penelitian, Suatu Pengantar

Pendidikan. In Rineka Cipta, Jakarta.

Budiman, \& Riyanto, A. (2014). Kapita Selekta Kuesioner Pengetahuan dan Sikap dalam Penelitian Kesehatan. Kapita Selekta Kuesioner Pengetahuan Dan Sikap Dalam Penelitian Kesehatan

Hanum, D. (2018). HUBUNGAN TINGKAT PENGETAHUAN IBU NIFAS TENTANG PERAWATAN LUKA PERINEUM DAN STATUS GIZI DENGAN PROSES PENYEMBUHAN LUKA. Journal of Economics, Business \& Accountancy Ventura. https://doi.org/10.14414/jebav.v $21 \mathrm{i} 2.1123$
Hidayah, N., \& Wulandari, F. (2016). ANALISA PENGETAHUAN IBU NIFAS TERHADAP TANDA BAHAYA BAYI BARU LAHIR. Profesi (Profesional Islam) : Media Publikasi Penelitian. https://doi.org/10.26576/profesi. 138

Kurniasari, L. (2019). Analisis Pelaksanaan Pencegahan Komplikasi Nifas di Wilayah Kerja Puskesmas Paal V Kota Jambi Tahun 2018. SCIENTIA JOURNAL. https://doi.org/10.35141/scj.v8i1. 436

Manuaba, I. (2014). Penyakit Kandungan dan KB Untuk Pendidikan Bidan. In Ilmu Kebidanan.

https://doi.org/10.1039/B9PY00 $221 \mathrm{~A}$

Muthoharoh, H. (2016). STUDI PENGETAHUAN IBU NIFAS TENTANG TANDA BAHAYA SELAMA MASA NIFAS (Di Desa Pomahan Janggan, Kecamatan Turi, Kabupaten Lamongan 2015). JURNAL KEBIDANAN. https://doi.org/10.30736/midpro. v8i1.6

Notoatmodjo, 2014. (2014). Konsep Pengetahuan, dan Sikap. Cell. https://doi.org/10.1016/j.cell.200 9.01 .043 
Nugraheni, I., \& Dyah, P. (2014). Perilaku Pantang Makanan Pada Ibu Nifas Di Wilayah Kerja Puskesmas Bayat Klaten Tahun 2014. Jurnal Ilmiah Rekam Medis Dan Informatika Kesehatan.

Nursalam. (2011). MANAJEMEN KEPERAWATAN Aplikasi dalam Praktik Keperawatan Profesional Edisi 3. Salemba Medika.

https://doi.org/10.1001/archinte. 165.22.2659

Nursalam, 2016, metode penelitian. (2013). Teori Lawrence Green. Journal of Chemical Information and Modeling. https://doi.org/10.1017/CBO978 1107415324.004

Nursalam. (2017). Metodologi penelitian ilmu keperawatan: pendekatan praktis. In Metodologi penelitian Iimu keperawatan: pendekatan praktis.

Pohan, A. (2017). JURNAL ILMIAH KOHESI Vol. 1 No. 1 April 2017. Ilmiah Kohesi.

Prawirohardjo, S. (2014). Ilmu Kebidanan. Jakarta . Bina Pustaka

Prisna, Florentina. (2009). Hubungan Tingkat Pengetahuan Ibu Nifas dengan Pengetahuan Ibu Nifas Tentang Tanda Bahaya Infeksi Nifas Dengan Kejadian Infeksi
Nifas Di Puskesmas Purwonegoro 1 Kabupaten Banjarnegara Tahun 2009. Program Studi D III Kebidanan Sekolah Tinggi Ilmu Kesehatan Jendral Ahmad Yani Yogyakarta 2010

Purwoastuti, E., \& Walyani, S. E. (2015). Pokok-pokok Ilmu Sosial dan Budaya Dasar pada Kebidanan. Pustaka Baru Press.

Sarwono, P. (2019). ilmu bedah kebidanan. Journal of Chemical Information and Modeling. https://doi.org/10.1017/CBO978 1107415324.004

Sumiyati, \& Latifah, H. (2015). STUDI PENGETAHUAN IBU NIFAS TENTANG TANDA BAHAYA SELAMA MASA NIFAS. In Jurnal Lisan Al-Hal.

Walyani, E. S., \& Purwoastuti, E. (2016). Asuhan Persalinan dan Bayi Baru Lahir. Yogyakarta.

Yayat, S., Kusyati, E., \& Hastuti, W. (2013). Hubungan Tingkat Pengetahuan Ibu Nifas Tentang Perawatan Luka Perineum Dan Status Gizi Dengan Proses Penyembuhan Luka di Poli KIA RS Pantiwilasa Citarum. Jurnal Managemen Keperawatan. https://doi.org/10.1016/j.ridd.200 6.03.004 